\title{
The Effect of IPR on the Condition of SMEs Survival; An Empirical Study of 800 SMEs of Company A from 1991 to the End of 2017 in Taiwan
}

\author{
Ching-Yung Wang \\ Department of International Business Studies, National Chi Nan University, Taiwan \\ *Corresponding author email: papa@seed.net.tw; james.cywang@msa.hinet.net
}

Received: 04 April 2018 / Revised: 14 April 2018 / Accepted: 16 April 2018 / Published: 22 April 2018

\begin{abstract}
Any powerful treatise comes from qualified enough evidence in Scientific Century 21th. Empirical research can supplement that lack of sufficient evidence to build stronger. There are many topics to discuss how important IPRs (Intellectual Property Rights) or ICs (Intellectual Property Rights Capital) are, but lack of advanced analysis for how separate countable IPRs affect SMEs in detail. We utilize 800 enterprises, which have a real trading record with company A from 1991 to 2017 and have paid tax to government, to analyze above problem through correlations, hypothesis and regression methods. The goal of this research is to supplement existing shortage evidence in details not to argue any questions for any researcher. We hope the outcome of this research can be a worthful and a better reference or guidance for those SMEs, or entrepreneurs, or managers, or government...etc. in the future. We know that power of life comes from the condition of Survival, at the same time, all continuous contribution of SMEs come from the condition of SMEs Survival, too. Here, the major goals of this study are how separate countable IPRs affects the condition of SMEs Survival to support those propositions, what emphasize the importance of IPRs. Finally, we suggest a guideline of IPRs investment priority sequence for those leaders or owners of entrepreneurs, SMEs...etc., who plan to make IPRs investment strategy decision.
\end{abstract}

Keywords: Intellectual Property Rights, Patent, Trademark, Enterprises, SMEs, Survival, Management.

\section{Introduction}

Upon the pursuing Development or Innovation of SMEs Profit \& Loss (P\&L), they must keep on going first. Enterprises, of course, include large SMEs and Small and Medium enterprises. For step 1 of our studies, we try to find many brutal facts, what invalid investment causes them to die? We do not need to admire or envy any ever or going-on splendid enterprises, because the results of the hero must be still alive in advance. If we talk about enterprises, what kinds of important things we shall study in advance, we believe that the condition of survival shall be a relative topic. SMEs (of course, include all large enterprises, following all we call SMEs) are the most important stability and social vitality of a country for almost countries around the world. No one can ignore or deny the contributions of SMEs on their country. SMEs cultivate enough careers opportunities to let the currencies flow fluently, or to let their country promote upgrade, or to compete with other countries. Those contribution and importance information can refer from WTO, European, WIPO. TIPO, SIPO, MOEA, OECD, U.S., that's why we are interested in studying SMEs here, especially for the condition of SMEs Survival. Although there are many propositions to be worth discussing upon SMEs' operation, for instance, business operation, module, strategy...etc. But we will focus on IPRs relative items here, at first.

The relative topics of studying and analyzing Small and Medium Sized Enterprises (SMEs) or Small Business (SBs) are very interesting and very important for themselves own countries, so as to understand their 
contribution like their important role in the growth and development of countries, to find any latent problem, to help to solve problem, to give a suitable guidance or support, and to protect secondary social problem, those as having the potential to become significant exporters, to promote economic growth, and to alleviate poverty among various groups in a society (Badrinath, 1997; Badrinath and Kirpal, 1997), having useful guidance for governments, policy makers, SMEs, industry associations and others in devising and evaluating SME policy and program (Wayne Wittig et al, 1998), having continued monitoring the economic conditions having an impact on SMEs and on the SME definition (.European Commission, 2009), having recommended a rationalization of EU programs and increased focus on the financial industries of member states and the EU consider establishing a more visible and effective point of contact for SMEs and VCs, having suggested observed and suggested that smaller enterprises internationalize better step by step from the Uppsala model (Van Den Bulcke, 2003)...etc. Upon the report from Japan, they found that there were $99.7 \%$ of all enterprises in the world are SME's and balance $0.30 \%$, are Large. We think we shall know more about SMEs at the first before we discuss them to avoid doing wrong or getting inadequate result. To prevent from diverting the topics of our study in SMEs, we will emphasis to concentrate on the condition of SMEs Survival at first.

According to most statistic data (OECD, WIPO 2012), they find that most contribution of social stability and labor careers, being close to $90 \%$, come from SMEs, but, the most contribution of national tax revenue, being close to 80\%, come from huge multi-national companies (HMNCs). Both SMEs and HMNCs have different organization structure, size, scale and operation situation, so, they can do business on their way. All they can face different degree of terrible crisis due to their nature and gene of firms. Especially, for SMEs, there may be no chance for them to make any loss because they have not sufficient resource, like capital, human or others to support themselves. The original gene of SMEs, like knowledge, technology or others, are too lack or shortage to spend more resource or spirit to do uncertainty. All SMEs can do only follow step by step gradually. Why does a firm exist and How does a firm sustain for a long time and What situation does firm need to possess qualify enough to fight his current competitors in actual market? What is the right answer for the last goal of a firm? To make money or to fulfill one's ideal or to let one's dream come true? To suffer lonely struggle during compete rivals in market or to be Invincible? It may be easy for anyone to start a new firm, but how to let this firm sustain long-term competitive with rivals will be a hard working for the key man of this firm. All we know that the first fundamental factors of SMEs survive will depend on their net profit income if the depth of his pocket isn't long enough. Even if long enough, firm may happen to a terrible crisis due to inappropriate decision making for R\&D strategy. So, if SMEs are not alive, above all contributions will be closed too. That's why we shall study the condition of SMEs Survival too.

For the firm, resources and products are two sides of the same coin. For SMEs, in order to survive, both side of coin cannot be neglected, but in practice, resources are more important than products, although most products require the services of several resources and most resources can be used in several products. From specifying the size of the firm's activity in different product markets, it can infer the minimum necessary resource commitments. Vice versa, from specifying a resource profile for a firm, it can find the optimal product-market activities. The resource position (strengths and weaknesses) of the firm is phrased by the traditional concept of strategy (Andrews, 1971), whereas most of our formal economic tools operate on the product-market side. While these two perspectives should ultimately yield the same insights, one might expect these insights to come with differing ease, depending on the perspective taken.

In Qxford dictionary, the definition of "survival" is "The state or fact of continuing to live or exist, typically in spite of an accident, or deal, or difficult circumstances", so, nothing shall be more important than how to Survival. Similarly, if SMEs are not survival, he will be nothing. It is the realism around the world, no one care what SME is ever, as long as SME has died, or even if he was ever IPO. For instance, who can we remember, how many SMEs are ever de-listed IPO, and who are ever IPO in Taiwan from 2001 to 2018 ? Who are still alive up to now? So, SMEs Survival is a great important subject for all SMEs' living problem. We believe that the priority subject of SMEs research shall be the condition of SMEs Survival according to 
Ching-Yung Wang., Adv. J Social Sci.; Vol. 3 Issue 1, pp: 8-22, 2018

our perspective. This is why we are very interested in study SMEs especially for their survival first. Although, there are many reasons for the condition of SMEs Survival, but we do experiment under our control data only, those as countable IPRs and the condition of SMEs Survival. Before studying IPRs and SMEs, we must re-confirm that the data of SMEs is absolutely correct and real entities come from company A. All they have real mutual trading relationship with company A up to now.

Following table 1 summarize more important events from those Announced White Book of SME administration Affairs of MOEA, in Taiwan in 2009, arranged by myself in 2018. We believe that there are similar situations around the world. Those data can let us know why we emphasize SMEs is very important for a country. SMEs release ten million career opportunities, the construct ratio of Lager Enterprises and Medium Enterprises are $14.22 \%$ vs. $76.57 \%$. Economic activity is close to 35 trillion NT dollars for income, 26 trillion NT dollars for Import, 9 trillion NT dollars for export. So, we can find the contribution of SMEs is too much to be forgotten.

Table 1: SMEs situation in 2008 in Taiwan Unit: No, Millions, thousand (Announced white book, 2009)

\begin{tabular}{|l|l|l|l|}
\hline & Total & Large Enterprise & Medium enterprise \\
\hline No. of Enterprise & $1,263,846$ & 29,097 & $1,234,749$ \\
\hline construct ratio & $100.00 \%$ & $2.30 \%$ & $97.70 \%$ \\
\hline employee(Thousand) & 10,403 & 1,479 & 7,966 \\
\hline construct ratio & $100.00 \%$ & $14.22 \%$ & $76.57 \%$ \\
\hline Income (Millions NT\$) & $35,239,137$ & $24,776,441$ & $10,462,696$ \\
\hline construct ratio & $100.00 \%$ & $70.31 \%$ & $29.69 \%$ \\
\hline import (Millions NT\$) & $25,762,915$ & $16,944,927$ & $8,817,989$ \\
\hline construct ratio & $100.00 \%$ & $65.77 \%$ & $34.23 \%$ \\
\hline export (Millions NT\$) & $9,476,222$ & $7,831,515$ & $1,644,707$ \\
\hline construct ratio & $100.00 \%$ & $82.64 \%$ & $17.36 \%$ \\
\hline
\end{tabular}

Following Table 2 show sales volume in year 2008, 2009 and 2010 in Taiwan, all data are arranged by myself, but come from Announced White Book in 2017, chapter 7, SME administration Affairs indicated the economic contribution of Sales volume. It indicates that SMEs give big currency flow in their country. The income sales volume of SMEs in 2008, 2009 and 2010 in Taiwan are 35 trillion NT dollars, 30 trillion NT dollars and 36 trillion NT dollars. That's the contribution of enterprises.

Table 2: Sales volume in Taiwan Unit: million NT\$ ; \% (MOEA)

\begin{tabular}{|l|l|l|l|l|l|l|}
\hline & Total & St. Ratio & SME & St. Ratio & LE & St. Ratio \\
\hline 2008 & $35,239,137$ & 100.00 & $10,462,696$ & 29.69 & $24,776,441$ & 70.31 \\
\hline 2009 & $29,981,803$ & 100.00 & $9,189,463$ & 30.65 & $20,792,340$ & 69.35 \\
\hline 2010 & $36,239,637$ & 100.00 & $10,709,005$ & 29.55 & $25,530,632$ & 70.45 \\
\hline
\end{tabular}

According to Announced White Book in 2017, chapter 7, from SME Administration Affairs, had a statistical analysis of SMEs Survival. During the content of section 1, it had pointed the importance of SMEs for country, being mentioned that SMEs supported a large labors market, wild supply chain and customer chain, and decreased monopoly market or exclusive market. In sec.2, it had mentioned the residual time periods of SMEs Survival too. SMEs concerned the affect to industries, labor market. All big enterprises start from SMEs, so, the condition of SMEs Survival is the fundamental and important key factor for SMEs, so as to be the center of gravity of economic development for a country. It's very pity that collected statistic data to be from 2000 to 2007, 7 years only, short time range, although it has collected over 20 close to 30 thousand of SMEs, from financial administration bureau in Taiwan. Refer to table 3, we can find. The 
The Effect of IPR on the Condition of SMEs Survival

shortage of that report only focused on the RES of Survival, lack of further research why they died or what factors affect the RES of Survival? The data belong to secondary data, short time period, maybe mix some empty enterprises. But our collected data from company A, have a long-time period, from 1991 to 2017, total 27 years, belong to primary data, and have formal trading record too, to be very rare and precious. In practice, those data belong to be confidential to be very hard to get to be analyzed.

Table 3: Operation Years of SMEs from 2000 to 2007 (Announce White Book, 2017)

\begin{tabular}{|l|r|r|r|r|r|r|r|r|}
\hline Res. Year & 2000 & 2001 & 2002 & 2003 & 2004 & 2005 & 2006 & 2007 \\
\hline$<1$ year & 96723 & 94803 & 91435 & 111510 & 108235 & 125313 & 108320 & 92957 \\
\hline CR & $\mathbf{9 . 0 4 \%}$ & $\mathbf{8 . 7 9 \%}$ & $\mathbf{8 . 2 8 \%}$ & $\mathbf{9 . 1 4 \%}$ & $\mathbf{9 . 3 0 \%}$ & $\mathbf{1 0 . 2 2 \%}$ & $\mathbf{8 . 7 0 \%}$ & $\mathbf{7 . 5 2 \%}$ \\
\hline $1 \sim 2$ & 99171 & 93598 & 94036 & 102869 & 109436 & 108019 & 120530 & 106082 \\
\hline CR & $\mathbf{9 . 2 7 \%}$ & $\mathbf{8 . 6 8 \%}$ & $\mathbf{8 . 5 1 \%}$ & $\mathbf{8 . 4 3 \%}$ & $\mathbf{9 . 4 0 \%}$ & $\mathbf{8 . 8 1 \%}$ & $\mathbf{9 . 6 8 \%}$ & $\mathbf{8 . 5 8 \%}$ \\
\hline $2 \sim 3$ & 84123 & 81967 & 77477 & 80861 & 86202 & 95033 & 92400 & 100057 \\
\hline CR & $\mathbf{7 . 8 6 \%}$ & $\mathbf{7 . 6 0 \%}$ & $\mathbf{7 . 0 1 \%}$ & $\mathbf{6 . 6 3 \%}$ & $\mathbf{7 . 4 1 \%}$ & $\mathbf{7 . 7 5 \%}$ & $\mathbf{7 . 4 2 \%}$ & $\mathbf{8 . 0 9 \%}$ \\
\hline $3 \sim 4$ & 71920 & 72092 & 70554 & 68208 & 69533 & 78119 & 83272 & 78070 \\
\hline CR & $\mathbf{6 . 7 2 \%}$ & $\mathbf{6 . 6 9 \%}$ & $\mathbf{6 . 3 9 \%}$ & $\mathbf{5 . 5 9 \%}$ & $\mathbf{5 . 9 7 \%}$ & $\mathbf{6 . 3 7 \%}$ & $\mathbf{6 . 6 9 \%}$ & $\mathbf{6 . 3 1 \%}$ \\
\hline $4 \sim 5$ & 56760 & 63123 & 63851 & 63589 & 59941 & 63649 & 70133 & 72474 \\
\hline CR & $\mathbf{5 . 3 0 \%}$ & $\mathbf{5 . 8 5 \%}$ & $\mathbf{5 . 7 8 \%}$ & $\mathbf{5 . 2 1 \%}$ & $\mathbf{5 . 1 5 \%}$ & $\mathbf{5 . 1 9 \%}$ & $\mathbf{5 . 6 3 \%}$ & $\mathbf{5 . 8 6 \%}$ \\
\hline $5 \sim 10$ & 241572 & 235959 & 233742 & 242604 & 239409 & 243123 & 247247 & 248543 \\
\hline CR & $\mathbf{2 2 . 5 7 \%}$ & $\mathbf{2 1 . 8 9 \%}$ & $\mathbf{2 1 . 1 6 \%}$ & $\mathbf{1 9 . 8 8 \%}$ & $\mathbf{2 0 . 5 7 \%}$ & $\mathbf{1 9 . 8 3 \%}$ & $\mathbf{1 9 . 8 6 \%}$ & $\mathbf{2 0 . 1 0 \%}$ \\
\hline $10 \sim 20$ & 252416 & 260541 & 279065 & 275349 & 279001 & 289745 & 290121 & 296123 \\
\hline CR & $\mathbf{2 3 . 5 8 \%}$ & $\mathbf{2 4 . 1 7 \%}$ & $\mathbf{2 5 . 2 6 \%}$ & $\mathbf{2 2 . 5 6 \%}$ & $\mathbf{2 3 . 9 7 \%}$ & $\mathbf{2 3 . 6 3 \%}$ & $\mathbf{2 3 . 3 0 \%}$ & $\mathbf{2 3 . 9 5 \%}$ \\
\hline over 20 & 167625 & 176079 & 194546 & 275349 & 212252 & 223094 & 233076 & 242240 \\
\hline CR & $\mathbf{1 5 . 6 6 \%}$ & $\mathbf{1 6 . 3 3 \%}$ & $\mathbf{1 7 . 6 1 \%}$ & $\mathbf{2 2 . 5 6 \%}$ & $\mathbf{1 8 . 2 3 \%}$ & $\mathbf{1 8 . 2 0 \%}$ & $\mathbf{1 8 . 7 2 \%}$ & $\mathbf{1 9 . 5 9 \%}$ \\
\hline Total & 1070310 & 1078162 & 1104706 & 1220339 & 1164009 & 1226095 & 1245099 & 1236546 \\
\hline CR & $\mathbf{1 0 0 . 0 0 \%}$ & $\mathbf{1 0 0 . 0 0 \%}$ & $\mathbf{1 0 0 . 0 0 \%}$ & $\mathbf{1 0 0 . 0 0 \%}$ & $\mathbf{1 0 0 . 0 0 \%}$ & $\mathbf{1 0 0 . 0 0 \%}$ & $\# \# \# \# \# \#$ & $\mathbf{1 0 0 . 0 0 \%}$ \\
\hline
\end{tabular}

Above Government data show that SMEs and their survival are the most important roles for their country. We survey and analysis the condition of SMEs Survival and how IPRs affect their Survival shall be a good topic.

\section{Research Data}

In practice, there are two types about SMEs, one is real operation, who have paid tax to country and have formal trading record in government; another is an empty company, who have no formal trading record and have no paying tax to country, just being established for some special purpose to be zero contribution on one's country, but maybe live with a latent crisis for his social stability in serious. The subject of this research simply focuses on those 800 real SMEs, who have real trading record and pay tax record with company A from 1991 up to the end of year 2017. Because all they are legal and have real entities and have real contribution to their country, meanwhile, population is more efficiency and reliability for SME's reference under our empirical analysis. There is different outcome to come out under different research condition; so, we proceed to study from 800 SMEs, population come from random pick-up from ten thousand of customers of company A.

Company A is established since June 1991, belongs to conservative management in Marketing, Human Resource, and Financial Operation, but positive and aggressive innovation in R\&D field. Company A has tens of thousands of SMEs, customers and suppliers, and business relationship partners with company A from 1991 up to now, because he has developed a self-software, what was a purpose output tool for printing, and has a relative corporation, what manufacture peripheral paper of computer. In spite of capital 
Ching-Yung Wang., Adv. J Social Sci.; Vol. 3 Issue 1, pp: 8-22, 2018

of company A is 5 million NT dollars only, but total employees are even from 3 persons up to 60 persons and down to 5 persons, he has invested his own copyrights, such as software, 16 IPRs granted by TIPO $(2 * \mathrm{INV}, 7 * \mathrm{MOD}, 2 * \mathrm{DES}, 11 * \mathrm{TRA})$ and granted by 7 developing countries, those as USA, Canada, German, UK, French, Japan, China, no borrowing interest-request money from outside. Now, his software is still running in market up to now.

The owner of company A had bachelor's degree in Mechanical Engineering, master's degree in Management, Study certificate of IPRs' program, including technology trading, licensing, from WIPO, National Cheng-Chi University, National Tsin- Hua University, ITRI. He is ever a corporate consultant and corporate lecturer on R\&D, ISO and manufacturing fields. He has been a consultant for hundreds of Entrepreneurs. He has been a part-time lecture in University for 11 years, too. He was ever a Branch Manager in Chinese group, Operation manager in USA enterprise, Co-builder in Japanese company to develop marketing in Taiwan and searching suppliers from Taiwan to Japan. He ever evaluated Hon Hai Precision Industry Co., Ltd, original of Foxconn Technology Group, to be a qualified supplier of Chinese Group when he worked at Chinese Group.

1. From Department of Commerce, MOEA.

2. From Intellectual Property Office, MOEA

3. From Market Observation Post System, MOPS

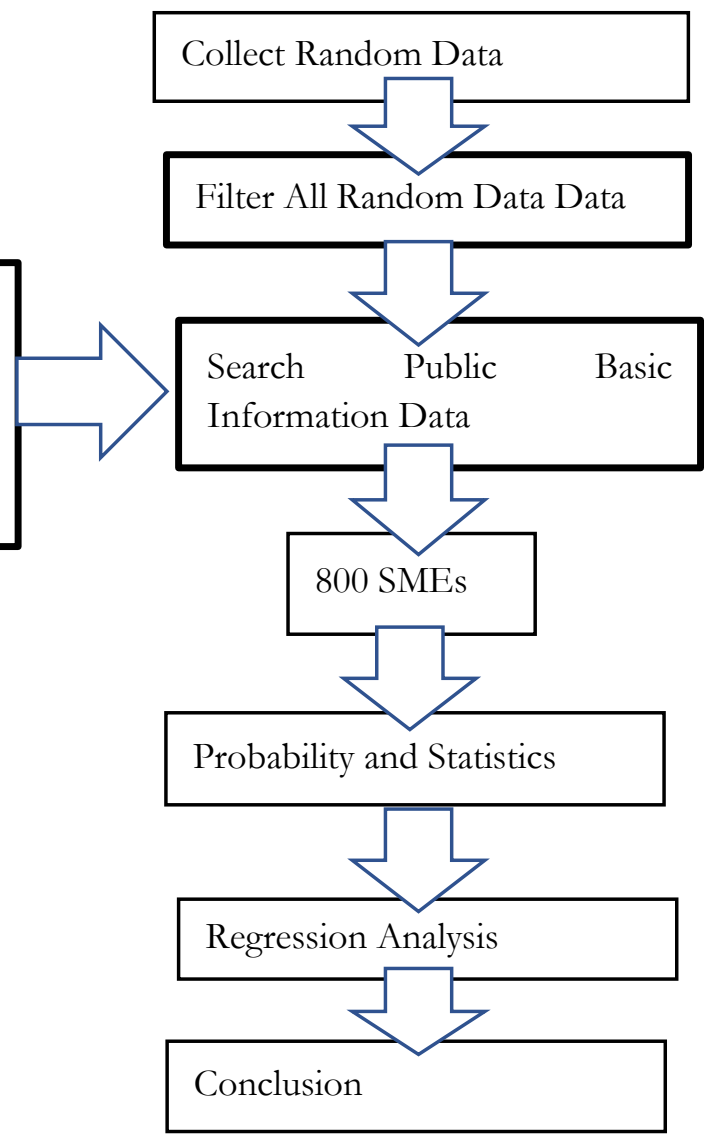

Figure 1: Research Flowchart

Data search flow chart can refer Figure 1. In practice, we know there are two types of SMEs, one type is real entities, and another type is like empty companies, just existing for some special purposes. So, all data of this empirical research, total 800 SMEs, come from the direct customers of company A, who established since 1991 up to now, total 27 years interval in Taiwan, and being still operating. The most important key point of this empirical research is all researched SMEs are real entities and having paid tax and real formal trading record with company A. All SMEs data belong to primary data, real entities, and legal enrolled in government. In practice, customers information of one's company belongs to trade secretary and all are hard to get. At first, we filter and double check the basic data of researched SMEs, those as established time, survival or not, revised date, capital, owners, close year... etc., form Ministry of Economic Affairs 
(MOEA) in Taiwan. We can get SMEs Survival data from MOEA. We know that the real value of anything depends on the real trade record, not being estimated only; all should be based on economy concept. IPRs are whole concept and belong to intangible assets. We are hard evaluating their real price. So, we try to divide IPRs into two types. One is countable IPRs, granted by the Taiwan Intellectual Property Office (TIPO), those as patent and Trademark; and another is uncountable IPRs, those as copyright, trade secretary...etc, all is hard to get and out of our control. Now, all countable IPRs we can get are Trademark (TRA), Invention (INV), Model (MOD) and Design (DES), all granted by TIPO in Taiwan. Then we survey who are IPO or not from Market Observation Post System (MOPS) in Taiwan. Finally, make conclusions after we analysis by construct ratio and Hypothesis and regression.

There are two subjects to discuss about SMEs Survival, one is die or not, we call it as Condition (CON), another is how long do SMEs sustain to operate, called Residual life(RES) here. Here, we discuss CON first, only. When SMEs want to preserve survival, they need enough competence to fight their competitors, and they shall know what kinds of parameter will affect their CON first. Is IC an important point for themselves to affect their survival? That is the most important reason why we will research and analysis in here. We suppose that IC has two types. One is tangible; and another is intangible. But here, we divide IC into another two types according to practice, one is countable and published information, those as Trademark, Patent...etc; and another is uncountable and unpublished information, those as copyright, trade secretary, etc. We study and analyze those countable IC here first, due to getting from government database. We neglect those uncountable IC due to being concerned confidential, being closed, and out of our control; all they are hard to get and to evaluate in depth due to concerning trade secretary of SMEs. We can only find two items of SMEs countable IPRs from government database, those as Patent (PAT) and Trademark (TRA) due to grant by Taiwan Intellectual Property Office (TIPO). We are hard to get others, those as copyright, trade secretary...etc,. So, all called IPRs here are only pointed to patent (PAT) and trademark (TRA). By the way, we separate PAT into three types, those as invention (INV), model (MOD) and design (DES). Summary, this study collects INV, MOD, DES, PAT, TRA and IPR with different assemblage pool as independent parameters, COD as dependent parameter to run SPSS tool according from these 800 SMEs individually to analyze and research their correlation, regression outcome, to get an empirical outcome. At the same time, we compare the outcome with another summary data arranged by ourselves in practice. There are some interesting outcomes to be close to practical phenomenon, although, the IPRs is very important for the condition of SMEs Survival, but there shall have different IPRs investment and IPRs strategy making in different IPRs pool.

Independent Variables $\quad$ Dependent variable

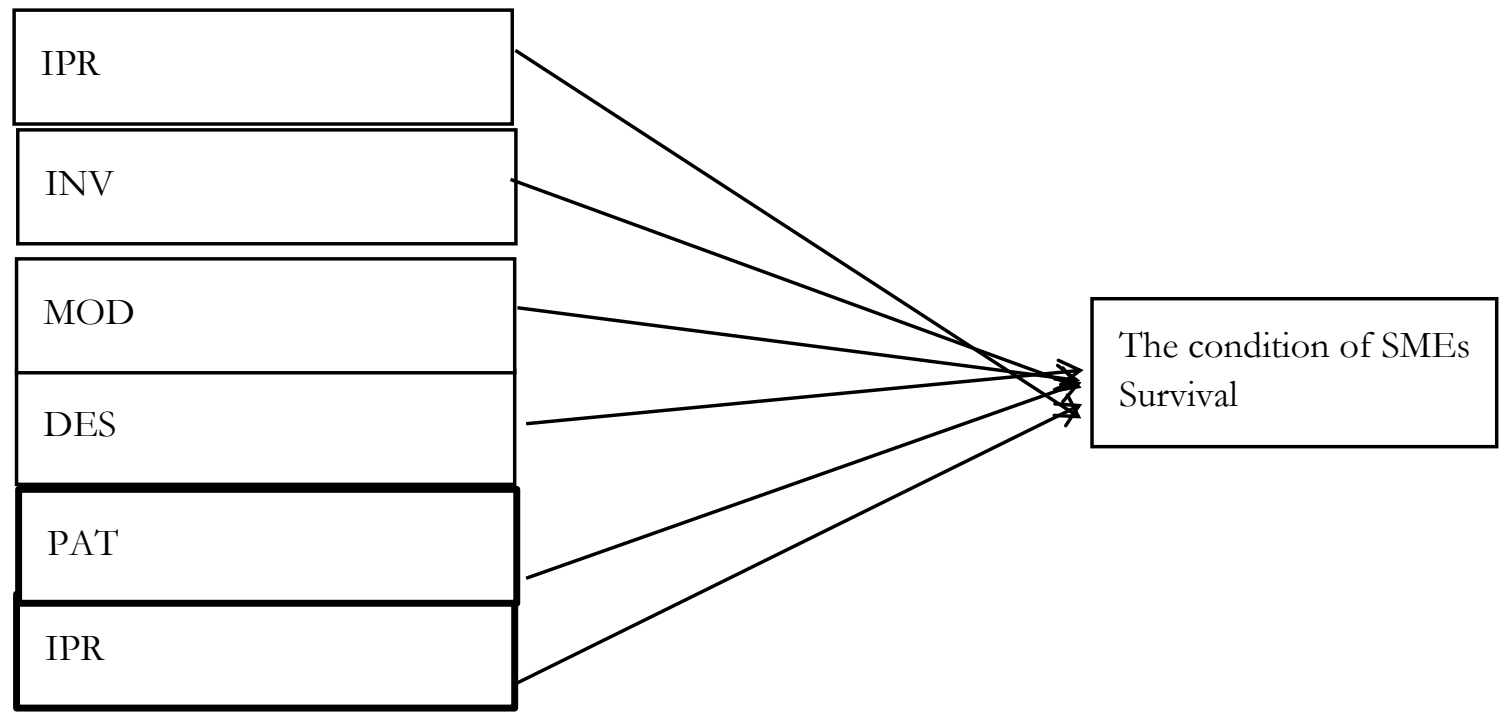

Figure 2: Research framework 


\section{Methodology}

\subsection{Research Framework}

Different item of countable IPRs has different investment strategy because there has different process and operation resource. And we can find 6 items of countable IPRs here only; they are IPR, INV, MOD, DES, PAT and TRA; we research how does individual IPRs affect the condition of SMEs Survival in 21th Century? We want to research following how the items of IPRs individual/assemblage (as independent variable) effect on the SMEs Survival (as dependent variable). Figure 2 shows our research framework.

\subsection{Hypothesis among Independent Variables vs. Dependent Variable}

Upon TIPO acts, INV, DES and TRA must pass examination of their content by ouside reviewer, but MOD reviews document paper only. All expense is different, pending time are different. So, we propose 6 null Hypothesis as table 4 and test them by correlations significant test to decide to reject/accept null hypothesis or not.

Table 4: Hypothesizes among Independent Variables vs. Dependent Variable

\begin{tabular}{|l|l|l|}
\hline No. & $\begin{array}{l}\text { Independent } \\
\text { Parameters }\end{array}$ & Correlation Hypothesis \\
\hline 1 & IPR & $H 1_{0}:$ IPR does not have impact on SMEs Survival. \\
\hline 2 & INV & $H 2_{0}:$ INV dose not have impact on SMEs Survival \\
\hline 3 & MOD & $H 3_{0}:$ MOD does not have impact on SMEs Survival. \\
\hline 4 & DES & $H 4_{0}:$ DES does not have impact on SMEs Survival. \\
\hline 5 & PAT & $H 5_{0}:$ PAT does not have impact on SMEs Survival. \\
\hline 6 & TRA & $H 6_{0}:$ TRA does not have impact on SMEs Survival. \\
\hline
\end{tabular}

\subsection{Regression SRM and MRM}

We pick up the individual item of countable IPRs as independent variable $\mathrm{x}$, those as INV, MOD, DES and TRA to analysis their effect on the condition of SMEs Survival as dependent variable y. So we use the Simple Regression Model (SRM), (Two-variable Linear Regression Model or Bivariate Linear Regression Model) to study their relationship. When $\mathrm{y}$ as dependent variable (or parameter), $\mathrm{x}$ as independent variable (or parameter), we are interested in "studying how y varies with changes in $\mathrm{x}$ ", or "explaining y in terms of x".

A SRM equation is

$$
\mathrm{y}=\beta_{0}+\beta_{1} x+u
$$

where

$\beta_{0}$ is the intercept parameter, or constant term.

$\beta_{1}$ is the Slop parameter in the relationship between $\mathrm{x}$ and $\mathrm{y}$.

" $u$ " is the error term or disturbance in the relationship, as factors other than $\mathrm{x}$ that affect $\mathrm{y}$.

Meanwhile, we assembly for items of countable IPRs as independent variable $x$, such as INV+MOD+DES+TRA to analysis his effect on the condition of SMEs Survival as dependent variable y. So we use the Multiple Regression Model (MRM), (Two-variable Linear Regression Model or Bivariate Linear Regression Model) to study their relationship and compare the relationship among each coefficient. It is more susceptible to other things equal to be analyzed, because it lets us explicitly control for many other factors that affect the dependent variable at the same time. For testing economic theories and evaluating policy effects are important if we must rely on nonexperimental data. To be able to accommodate many explanatory variables where may be correlated, we can hope to infer causality in case of where SRM would be misleading. Figure 3 shows conceptual framework of the condition of SMEs survival and IPR. 
A MRM equation is :

$$
\mathrm{y}=\beta_{0}+\sum_{i=1}^{n} \beta_{i} x_{i}+u
$$

where

$\beta_{0}$ is the intercept

$\beta_{i}$ measures the change in y with respect to $x_{i}$, holding other factors fixed.

" $\mathrm{u}$ " is the error term or disturbance in the relationship, as factors other than $\sum_{i=1}^{n} \beta_{i} x_{i}$ that affect $\mathrm{y}$

For instance, in case A, IPRs is independent parameter; and COD is dependent variable.

INDP means independent variable.

$$
\mathrm{F}(\mathrm{x})=\beta_{0}+\sum_{i=1}^{n}\left(\beta_{i} I N D P_{i}\right)+u
$$

Where

$\mathrm{F}(\mathrm{x})=\beta_{0}+\sum_{i=1}^{n}\left(\beta_{i} I N D P_{i}\right)+u$

a : $\mathrm{i}=1=\mathrm{IPR}$

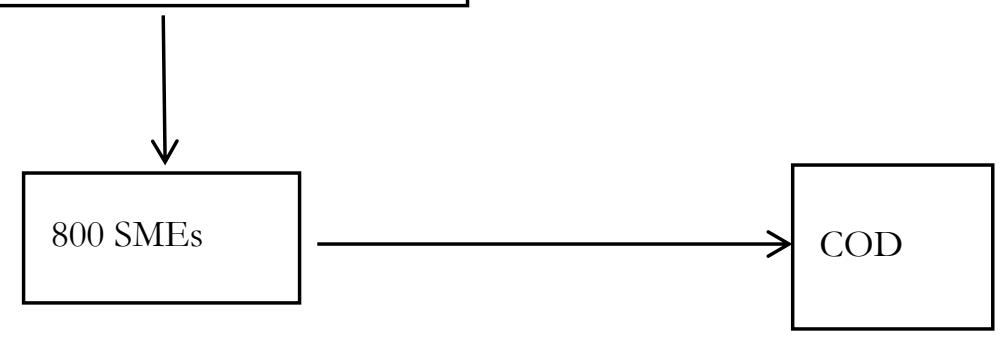

b : $\mathrm{i}=1=$ PAT, $\mathrm{i}=2=\mathrm{TRA}$

c : $\mathrm{i}=1=\mathrm{INV}, \mathrm{i}=2=\mathrm{MOD}, \mathrm{i}=3=\mathrm{DES}, \mathrm{i}=4=\mathrm{TRA}$

$\mathrm{d}: \mathrm{i}=1=\mathrm{INV}$

e : $\mathrm{i}=1=\mathrm{MOD}$

$\mathrm{f}: \mathrm{i}=1=\mathrm{DES}$

$\mathrm{g}: \mathrm{i}=1=$ PAT

h : $\mathrm{i}=1=\mathrm{TRA}$

Figure 3: Conceptual Framework of the condition of SMEs Survival and IPR

\section{Results and Discussion}

\subsection{Graph of Data information}

From Fig 4, we can find the distribution of the established time of the 800 researched SMEs, who were established since1939 to 2017, total around 79 years interval, scope from older to younger. It is close to normal distribution population. Most of those SMEs still have good relationship with company A up to now.

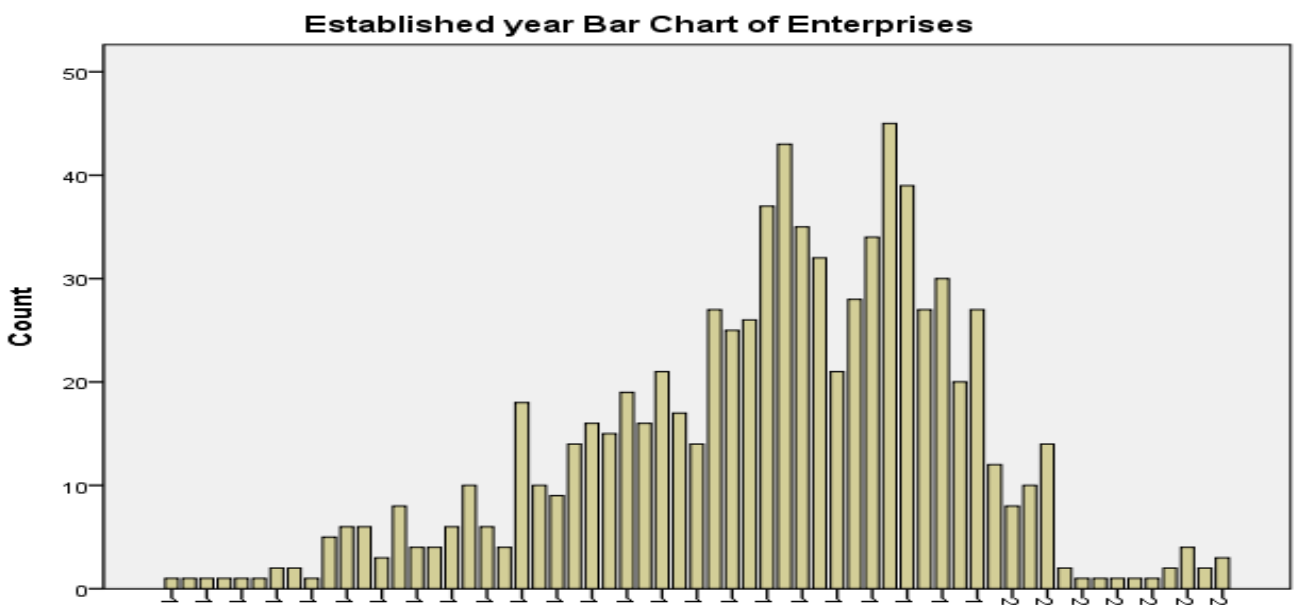

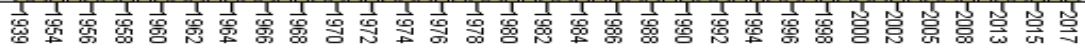
EST

Figure 4: Bar chart of SMEs established time 
Ching-Yung Wang., Adv. J Social Sci.; Vol. 3 Issue 1, pp: 8-22, 2018

From Fig 5, we can find the distribution of the residual time of 800 researched SMEs, who still keep on operating from 1 year to 66 years interval, scope from younger companies to older companies too.

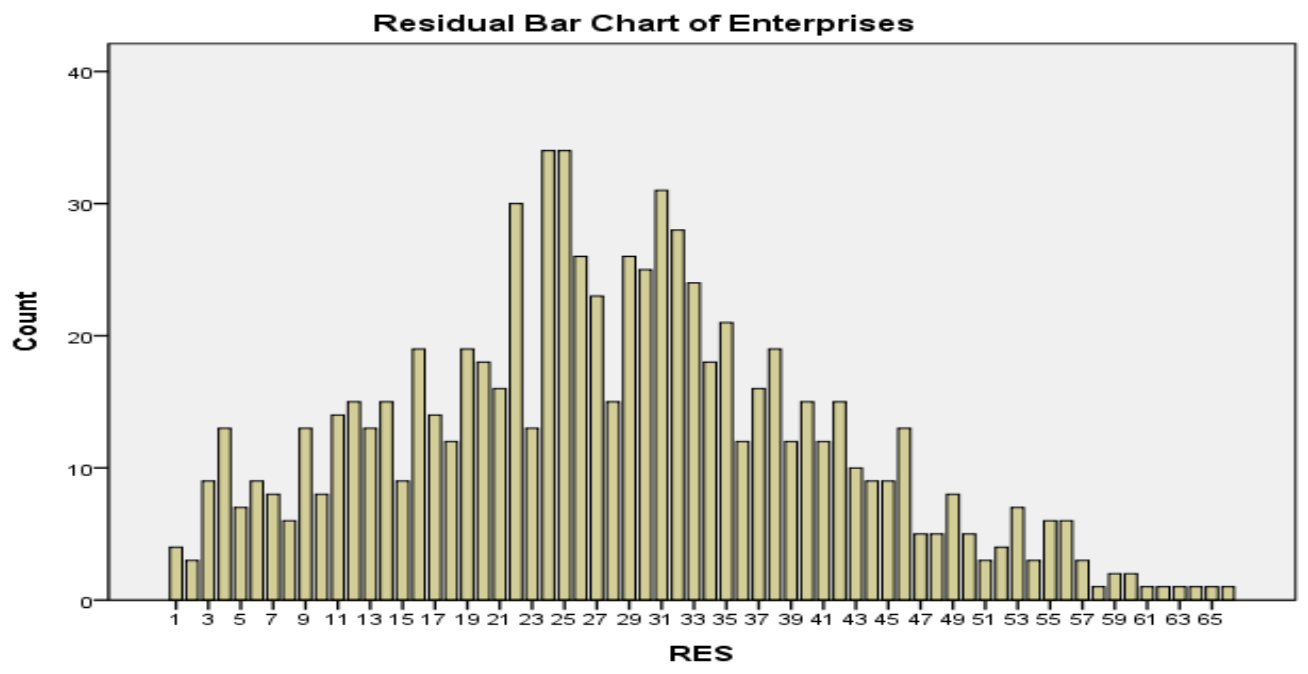

Figure 5: Bar chart of SMEs Residual time

\subsection{Measurement Descriptive Statistic}

From table 5 measurement Descriptive Statistic, the mean of CON, INV, MOD, DES, PAT, TRA, IPR is $.68,9.81,8.71,3.28,21.82,12.35$, and 34.17. The standard Deviation is .466, 105.249, 34.602, 23.157, $132.087,49.266$ and 170.157.

Table 5: Measurement Descriptive Statistic

\begin{tabular}{|l|l|l|l|l|l|l|}
\hline & N & Minimum & Maximum & Sum & Mean & Std. Deviation \\
\hline CON & 800 & 0 & 1 & 546 & 68 & .466 \\
EST & 800 & 1939 & 2017 & 1589069 & 1986.34 & 10.709 \\
RES & 800 & 1 & 79 & 22287 & 27.86 & 13.160 \\
INV & 800 & 0 & 2699 & 7847 & 9.81 & 105.249 \\
MOD & 800 & 0 & 603 & 6972 & 8.71 & 34.602 \\
DES & 800 & 0 & 551 & 2625 & 3.28 & 23.157 \\
PAT & 800 & 0 & 2922 & 17454 & 21.82 & 132.087 \\
TRA & 800 & 0 & 856 & 9880 & 12.35 & 49.266 \\
IPR & 800 & 0 & 3422 & 27334 & 34.17 & 170.157 \\
\hline
\end{tabular}

\subsection{Correlations}

From table $6 \mathrm{a}$, b correlations, we can find that INV is not significant, 0.093; DES is light significant, .029; MOD, PAT, TRA and IPR are significant, 0, .006, 0 and .002. Meanwhile, we can make a Hypothesis result as table 7. We reject null hypothesis to MOD, DES and TRA exclude INV.

Because we use correlations hypothesis test, according to the symbol of the running result of correlations, there are 3 types of correlations. We reject null hypothesis and change to accept Alternative Hypothesis $H_{1}$, when correlation have "* " symbol or " **" symbol, otherewise we will not reject null hypothesis but accept $H_{0}$

So, we summarize following table 7 correlative Hypotheses according to significant of correlations. We find that we don't reject null hypotheses at INV. So, we argue that INV does not affect the condition of SMEs Survival. On the other hand, we reject null hypotheses and change accept alternative hypotheses on IPR, MOD, DES, PAT and TRA, all they will affect to the condition of SMEs Survival.

From table 6a, b correlations, we can summarize all result of Hypothesis according correlations test as following table 7. All IPR, MOD, DES, PAT and TRA are reject null Hypothesis but accept alternative 
The Effect of IPR on the Condition of SMEs Survival

Hypothesis, depend on correlative test, they are "will have impact on SMEs Survival." exclude INV, can’t reject null Hypothesis, “INV does not have impact on SMEs Survival.".

Table 6 a: Measurement Correlations Statistic

\begin{tabular}{|c|c|c|c|c|c|c|c|c|c|c|}
\hline & & $\mathrm{CON}$ & EST & RES & INV & MOD & DES & PAT & TRA & IPR \\
\hline \multirow[t]{2}{*}{$\mathrm{CON}$} & $\begin{array}{l}\text { Pearson } \\
\text { Correlation }\end{array}$ & 1 & $-.158 * *$ & $.553 * *$ & 0.059 & $.136^{* *}$ & $.077^{*}$ & $.097 * *$ & $.126^{* *}$ & $.112 * *$ \\
\hline & Sig. (2-tailed) & & 0 & 0 & 0.093 & 0 & 0.029 & 0.006 & 0 & 0.002 \\
\hline \multirow[t]{2}{*}{ EST } & $\begin{array}{l}\text { Pearson } \\
\text { Correlation }\end{array}$ & & 1 & $-.861 * *$ & $-.121 * *$ & $-.178 * *$ & $-.168 * *$ & $-.173 * *$ & $-.271 * *$ & $-.213^{* *}$ \\
\hline & Sig. (2-tailed) & & & 0 & 0.001 & 0 & 0 & 0 & 0 & 0 \\
\hline \multirow[t]{2}{*}{ RES } & $\begin{array}{l}\text { Pearson } \\
\text { Correlation }\end{array}$ & & & 1 & $.123 * *$ & $.205 * *$ & $.170 * *$ & $.183 * *$ & $.275^{* *}$ & $.221 * *$ \\
\hline & Sig. (2-tailed) & & & & 0 & 0 & 0 & 0 & 0 & 0 \\
\hline \multirow[t]{2}{*}{ INV } & $\begin{array}{l}\text { Pearson } \\
\text { Correlation }\end{array}$ & & & & 1 & $.413 * *$ & $.228 * *$ & $.945 * *$ & $.572 * *$ & $.899 * *$ \\
\hline & Sig. (2-tailed) & & & & & 0 & 0 & 0 & 0 & 0 \\
\hline \multirow[t]{2}{*}{ MOD } & $\begin{array}{l}\text { Pearson } \\
\text { Correlation }\end{array}$ & & & & & 1 & $.322 * *$ & $.647 * *$ & $.606 * *$ & $.678^{* *}$ \\
\hline & Sig. (2-tailed) & & & & & & 0 & 0 & 0 & 0 \\
\hline \multirow[t]{2}{*}{ DES } & $\begin{array}{l}\text { Pearson } \\
\text { Correlation }\end{array}$ & & & & & & 1 & $.442 * *$ & $.475^{* *}$ & $.480 * *$ \\
\hline & Sig. (2-tailed) & & & & & & & 0 & 0 & 0 \\
\hline
\end{tabular}

Table 6 b: Measurement Correlations Statistic - to be continue

\begin{tabular}{|c|c|c|c|c|c|c|c|c|c|}
\hline & & $\begin{array}{ll}\text { CON EST } \\
\end{array}$ & RES & INV & MOD & DES & PAT & TRA & IPR \\
\hline \multirow[t]{2}{*}{ PAT } & $\begin{array}{l}\text { Pearson } \\
\text { Correlation }\end{array}$ & & & & & & 1 & $.698 * *$ & $.978 * *$ \\
\hline & Sig. (2-tailed) & & & & & & & 0 & 0 \\
\hline \multirow[t]{2}{*}{ TRA } & $\begin{array}{l}\text { Pearson } \\
\text { Correlation }\end{array}$ & & & & & & & 1 & $.831 * *$ \\
\hline & Sig. (2-tailed) & & & & & & & & 0 \\
\hline IPR & $\begin{array}{l}\text { Pearson } \\
\text { Correlation } \\
\text { Sig. (2-tailed) }\end{array}$ & & & & & & & & 1 \\
\hline
\end{tabular}

Table 7: Correlative Hypothesis

\begin{tabular}{|l|l|l|l|}
\hline No. & $\begin{array}{l}\text { Independent } \\
\text { Parameters }\end{array}$ & Correlation Hypothesis & Correlations. \\
\hline 1 & IPR & $\boldsymbol{H 1}_{\mathbf{1}}:$ IPR will have impact on SMEs Survival. & $.112^{* *}$ \\
\hline 2 & INV & $H 2_{0}:$ INV does not have impact on SMEs Survival. & 0.59 \\
\hline 3 & MOD & $\boldsymbol{H 3}_{\mathbf{1}}:$ MOD will have impact on SMEs Survival. & $.136^{* *}$ \\
\hline 4 & DES & $\mathbf{H 4}_{\mathbf{1}}:$ DES will have impact on SMEs Survival. & $.077^{*}$ \\
\hline 5 & PAT & $\mathbf{H 5}_{\mathbf{1}}:$ PAT will have impact on SMEs Survival. & $.097^{* *}$ \\
\hline 6 & TRA & $\mathbf{H 6}_{\mathbf{1}}:$ TRA will have impact on SMEs Survival. & $.126^{* *}$ \\
\hline
\end{tabular}




\subsection{SRM and MRM}

From table 8 to table 15 Regression equations, we put all individual coefficients on two types of regression formula, one type of coefficients is unstandardized; and another type is standardized. Because we find that there are some unstandardized coefficients (Unstd Coefs) in regression analysis is zero, according to the output of IBM SPSS 23 tool, that's unreasonable, why? Maybe those Unstd Coefs are too very small close to zero to be calculated, so, neglect them. In order to get clearer formula, we put Unstd Coefs on regression formula.

All output formula here, Coefficients, have been surveyed or Test by SPSS tool, those as Variables Entered/Removed, Model Summary, ANOVA Test and Residuals Statistics in advance. We can find $\mathrm{R}^{2}$ for every case to be $0.013,0.016,0.022,0.004,0.018,0.006,0.009$ and 0.016. Although they are bad goodness, but ANOVA Test is significant in case A, $0.002<0.05$, case $\mathrm{B}, 0.002<0.05$, Case $\mathrm{C}, 0.001<0.05$, case E, $0.000<0.05$, case F, $0.029<0.05$, case G, $0.006<0.05$, and Case $\mathrm{H}, 0.000<0.05$, exclude Case D, $0.93>0.05$, Independent variable of Case D being INV. Maybe we support that INV investment of IPR in 800 SMEs is not absolutely necessary because the business model of most SMEs here is OEM and less having self-end-products or self-brand-product in market, Most of them are OEM or trading-end only.

Although most of Regression coefficients are very small, but it has been proved that almost all countable IPRs items affect to the condition of SMEs Survival from empirical research, being found by running SPSS, not to mention including those all uncountable IPRs. So, we can directly indicate that all IPRs shall affect to the condition of SMEs Survival if we plus uncountable IPRs.

In practice, INV is a big investment for the operation of most SMEs; especially for those resource limited SMEs or unnecessary use enterprises, because of high expense and long pending time, to be a hard way for SMEs. So, the result, what INV does not affect to the condition of SMEs Survival, appear on this empirical research. INV investment is not only way for SMEs to invest IPR, there are many ways for the IPR investment of SMEs to promote competitiveness themselves, those as trade secretary, copyright...etc.

We arrange all Coefficients table and equations for Regression Model of the condition of SMEs Survival; for concerning assemblage pool of IPRs, there are 8 cases, from case A to case $\mathrm{H}$.

Case A. Independent parameter is IPR. R Square equals to .013.

From table 8, SRM of IPR, we can find that the coefficient of the effect of IPR on COD is significant, .002 .

Table 8: Coefficients for IPR

\begin{tabular}{|c|c|c|c|c|c|}
\hline \multirow[b]{2}{*}{ Model } & \multicolumn{2}{|c|}{ Unstd Coefs } & \multirow{2}{*}{$\frac{\text { Sstd Coefs }}{\text { Beta }}$} & & \multirow[b]{2}{*}{ Sig. } \\
\hline & $B$ & Std. Error & & t & \\
\hline (Constant) & .672 & .017 & & 40.236 & .000 \\
\hline IPR & .000 & .000 & .112 & 3.178 & .002 \\
\hline
\end{tabular}

Case B. Independent parameter is PAT+TRA. R Square equals to.016.

From table 9 SRM of PAT+TRA, we can find that the coefficient of the affect of PAT+TRA on COD is not significant and significant, .711 and .021 .

Table 9: Coefficients for TRA+PAT

\begin{tabular}{|l|l|l|l|l|l|}
\hline \multirow{2}{*}{ Model } & \multicolumn{2}{|l|}{ Unstd Coefs } & Sstd Coefs & & \multirow{2}{*}{ Sig. } \\
\cline { 2 - 4 } & $\mathrm{B}$ & Std. Error & Beta & $\mathrm{t}$ & .000 \\
\hline 1 (Constant) & .668 & .017 & & 39.603 & .000 \\
PAT & $6.412 \mathrm{E}-5$ & .000 & .018 & .371 & .711 \\
TRA & .001 & .000 & .113 & 2.307 & .021 \\
\hline
\end{tabular}

Case C. Independent parameter is INV+MOD+DES+TRA. R Square equals to.022.

From table $10 \mathrm{MRM}$ of INV+MOD+DES+TRA, we can find that the coefficients of the effect of MOD is significant .031; but INV, DES and TRA on COD are not significant, .53, .675 and .155. 
Table 10: Coefficients for TRA+DES+INV+MOD

\begin{tabular}{|c|c|c|c|c|c|c|}
\hline \multirow{2}{*}{\multicolumn{2}{|c|}{ Model }} & \multicolumn{2}{|c|}{ Unstd Coefs } & \multirow{2}{*}{\begin{tabular}{|l} 
Sstd Coefs \\
Beta
\end{tabular}} & \multirow[b]{2}{*}{$\mathrm{t}$} & \multirow[b]{2}{*}{ Sig. } \\
\hline & & B & Std. Error & & & \\
\hline \multirow[t]{5}{*}{1} & (Constant) & .663 & .017 & & 38.970 & .000 \\
\hline & INV & .000 & .000 & -.027 & -.628 & .530 \\
\hline & MOD & .001 & .001 & .096 & 2.163 & .031 \\
\hline & DES & .000 & .001 & .017 & .420 & .675 \\
\hline & TRA & .001 & .000 & .075 & 1.422 & .155 \\
\hline
\end{tabular}

Case D. Independent parameter is INV. R Square equals to.004.

From table 11 SRM of INV, we can find that the coefficient of the effect of INV on COD is not significant, .093 .

Table 11: Coefficients For INV

\begin{tabular}{|c|c|c|c|c|c|c|}
\hline \multirow{2}{*}{\multicolumn{2}{|c|}{ Model }} & \multicolumn{2}{|c|}{ Unstd Coefs } & \multirow{2}{*}{\begin{tabular}{|l} 
Sstd Coefs \\
Beta
\end{tabular}} & \multirow[b]{2}{*}{$\mathrm{t}$} & \multirow[b]{2}{*}{ Sig. } \\
\hline & & B & Std. Error & & & \\
\hline 1 & (Constant) & .680 & .017 & & 41.155 & .000 \\
\hline & INV & .000 & .000 & .059 & 1.679 & .093 \\
\hline
\end{tabular}

Case E. Independent parameter is MOD. R Square equals to.018.

From table 12 SRM of MOD, we can find that the coefficient of the effect of MOD on COD is not significant, .000.

Table 12: Coefficients for MOD

\begin{tabular}{|c|c|c|c|c|c|}
\hline \multirow[b]{2}{*}{ Model } & \multicolumn{2}{|c|}{ Unstd Coefs } & \multirow{2}{*}{$\begin{array}{l}\text { Sstd Coefs } \\
\text { Beta }\end{array}$} & \multirow[b]{2}{*}{ t } & \multirow[b]{2}{*}{ Sig. } \\
\hline & $\mathrm{B}$ & Std. Error & & & \\
\hline $1 \quad$ (Constant) & .667 & .017 & & 39.591 & .000 \\
\hline MOD & .002 & .000 & .136 & 3.872 & .000 \\
\hline
\end{tabular}

Case F. Independent parameter is DES. R Square equals to.006.

From table 13 SRM of DES, we can find that the coefficient of the affect of DES on COD is not significant, .029 .

Table 13: Coefficients for DES

\begin{tabular}{|c|c|c|c|c|c|c|}
\hline \multirow{2}{*}{\multicolumn{2}{|c|}{ Model }} & \multicolumn{2}{|c|}{ Unstd Coefs } & \multirow{2}{*}{\begin{tabular}{|l} 
Sstd Coefs \\
Beta
\end{tabular}} & \multirow[b]{2}{*}{$\mathrm{t}$} & \multirow[b]{2}{*}{ Sig. } \\
\hline & & B & Std. Error & & & \\
\hline \multirow[t]{2}{*}{1} & (Constant) & .677 & .017 & & 40.823 & .000 \\
\hline & DES & .002 & .001 & .077 & 2.188 & .029 \\
\hline
\end{tabular}

Case G. Independent parameter is PAT. R Square equals to.009.

From table 14 SRM of PAT, we can find that the coefficient of the effect of PAT on COD is not significant, .006 .

Table 14: Coefficients for PAT

\begin{tabular}{|l|l|l|l|l|l|}
\hline \multirow{2}{*}{ Model } & \multicolumn{2}{l|l|l|l|}{ Sstd Coefs } & & \multirow{2}{*}{ Sig. Coefs } \\
\cline { 2 - 5 } & B & Std. Error & Beta & $t$ & Sig. \\
\hline 1 (Constant) & .675 & .017 & & 40.607 & .000 \\
PAT & .000 & .000 & .097 & 2.756 & .006 \\
\hline
\end{tabular}


Ching-Yung Wang., Adv. J Social Sci.; Vol. 3 Issue 1, pp: 8-22, 2018

Case H. Independent parameter is TRA. R Square equals to.016.

From table 15 SRM of TRA, we can find that the coefficient of the effect of TRA on COD is not significant, .000 .

Table 15: Coefficients for TRA

\begin{tabular}{|l|l|l|l|l|l|}
\hline \multirow{2}{*}{ Model } & \multicolumn{2}{|l|}{$\begin{array}{l}\text { Standardized } \\
\text { Coefficients }\end{array}$} & & \\
\cline { 2 - 5 } & Unstd Coefs & Std. Error & Beta & $\mathrm{t}$ & Sig. \\
\hline 1 (Constant) & .668 & .017 & & 39.623 & .000 \\
TRA & .001 & .000 & .126 & 3.583 & .000 \\
\hline
\end{tabular}

We can summarize table 8 to table 15 to replace all coefficients of each regression on formula to get table 16. From every coefficient of SRM is significant exclude INV. In practice, INV investment is hard to grant from TIPO; must exhaust much money and other resources; must spend too much time to spend and revise process. INV is also not easy to commercialize and utilize, if its content does not qualify enough because that most of INV focus on fundamental science. DES emphasizes its shape and graph, protecting range is too small to infringe competitors. SMEs must invest too much for every type or model of products, not economic. For Marketing and Brand, MOD, granted from TIPO, is easier than INV and DES; to get certificate equals to get protect for manufacture and sales. The strategy of TRA investment is for marketing and build up the self-brand of SMEs. So, DES and TRA are significant.

Table 16: Regression formula result

\begin{tabular}{|c|c|c|}
\hline No. & case & Regression Result \\
\hline 1 & Case A & $\begin{array}{l}C O D_{\text {Unstd }}=.672^{* * *}+\left(0.000^{* * *}\right) x_{I P R} \\
C \widehat{O N}_{\text {std. }}=0.672^{* * *}+0 . \overline{112}^{* * *} x_{I P R}\end{array}$ \\
\hline 2 & Case B & $\begin{array}{l}C O D_{\text {Unstd }}=.668^{* * *}+(6.412 \mathrm{E}-5) x_{P A T}+.001^{* *} x_{T R A} \\
C \widehat{O N_{\text {std. }}}=.668^{* * *}+\widehat{0.018 x_{P A T}+0.113^{* *} x_{T R A}}\end{array}$ \\
\hline 3 & Case C & $\begin{aligned} & C O D_{\text {Unstd }}=.663^{* * *}+(.000) x_{I N V}+.001^{* *} x_{M O D}+(.000) x_{D E S} \\
&+(.001) x_{T R A} \\
& C \widehat{O N}_{\text {Std. }}=.663^{* * *}+-\widehat{.027 x_{I N V}}+.096^{* *} x_{M O D}++. \widehat{017} x_{D E S}+. \widehat{075} x_{T R A}\end{aligned}$ \\
\hline 4 & Case D & $\begin{array}{l}C O D_{\text {Unstd }}=.680^{* * *}+\left(0.000^{*}\right) x_{I N V} \\
\text { CoN }_{\text {std. }}=.680^{* *}+. \overline{059}^{*} x_{I N V}\end{array}$ \\
\hline 5 & Case $\mathrm{E}$ & $\begin{array}{l}C O D_{\text {Unstd }}=.667^{* * *}+.002^{* * *} x_{M O D} \\
\text { CoN }_{\text {std. }}=.667^{* * *}+.136^{* * *} x_{M O D}\end{array}$ \\
\hline 6 & Case F & $\begin{array}{l}C O D_{\text {Unstd }}=.677^{* * *}+.002^{* *} x_{D E S} \\
C \widehat{O N_{\text {std. }}}=.677^{* * *}+.077^{* *} x_{D E S}\end{array}$ \\
\hline 7 & Case $\mathrm{G}$ & $\begin{array}{l}C O D_{\text {Unstd }}=.675^{* * *}+\left(0.000^{* * *}\right) x_{P A T} \\
C \widehat{O N}_{\text {std. }}=.675^{* * *}+.097^{* * *} x_{P A T}\end{array}$ \\
\hline 8 & Case $\mathrm{H}$ & $\begin{array}{l}C O D_{\text {Unstd }}=.668^{* * *}+.001^{* * *} x_{\text {TRA }} \\
C \widehat{O N_{\text {std. }}}=.668^{* * *}+. \overline{126}^{* * *} x_{T R A}\end{array}$ \\
\hline
\end{tabular}

\section{Conclusions}

IPRs is like water, it can float SMEs or overturns SMEs depending on whether SMEs invest it by which side. SMEs must have a sense of self-esteem in advance when they want to invest IPRs. Regarding as our empirical research, we all know that countable IPRs are very important for SMEs in 21 th century; but it's impossible for SMEs to invest all items of IPRs due to limited resource. We find that countable IPRs really affect the condition of SMEs Survival; but there are many different assemblage pools of countable IPRs; SMEs have too limited resources to invest all. They can select the best way of IPRs investment for themselves, referring priority sequence advice of our empirical research, when they cannot but face 
infringement problem of IPR; We find that IPR, PAT, TRA, MOD have impact on the condition of SMEs Survival significantly; DES has slightly significant impact on the condition of SMEs; INV does not have impact on the condition of SMEs. This result gives further evidence for those treatises to persuade their readers how IPRs are important; we suggest that the priority sequence of individual countable IPRs investment is MOD $>$ TRA $>$ IPR $>$ PAT $>$ DES > INV, according to correlations $p$ value, SRM and MRM. Our outcome will be a good guideline and reference not only for SMEs, but also for all SOHO, firms, and government, especially for those entrepreneurs who plan to start up a SME. We suggest all entrepreneurs that they start from newer customers when they plan to enter into market, because no one knows them, and older customers have their own- existing suppliers and have no idea about you, lack of trust relationship, they must spend in patience. This research can supplement and strengthen sufficient empirical evidence for lack of more detail and clear information in existing management field. We must do right thing at first, then we can do things right.

\section{How to Cite this Article:}

Ching-Yung, W. (2018, April 22). The Effect of IPR on the Condition of SMEs Survival; An Empirical Study of 800 SMEs of Company A from 1991 to the End of 2017 in Taiwan. Advanced Journal of Social Science, 3(1), 8-22. doi: $10.21467 /$ ajss.3.1.8-22

\section{Reference}

Announced white book in 2009 by SME Administration, Ministry of Economic Affairs.

Badrinath, R. (1997). The SME in the Global Marketplace: An Analysis of Competitiveness.

Badrinath, R. and A. Kirpal (1997). The SME and the Export Development Company: A Practical Guide to Forging Long-Term Business Relationships in the Export Sector, International Trade Centre.

European Commision, (2009) Commission Staff Working Document 'on the implementation of Commission Recommendation of 6 May 2003 concerning the definition of micro, small and medium-sized enterprises'.

MOEA; Ministry of economic affairs, Taiwan.

Oecd working party on smes and entrepreneurship, (2010), 'Issues paper 1: Innovative SMEs and entrepreneurship for job creation and growth'.

OECD WORKING PARTY ON SMES AND ENTREPRENEURSHIP, (2010), 'Issues paper 2: Better SME and entrepreneurship financing for job creation and growth'.

OECD WORKING PARTY ON SMES AND ENTREPRENEURSHIP, (2010), 'Issues paper 3: SMEs and green growth: Promoting sustainable manufacturing and eco-innovation in small firms'.

OECD, Enhancing the Role of SMEs in Global Value Chains, 2007.

OECD, Top Barriers and Drivers to SME Internationalization, 2009.

Paul Germeraad, (1999). 'Intellectual Property in a Time of Change. Research.Technology Management.'

Peter K, Yu (2007). Intellectual Property and Information Wealth: Copyright and related rights]. Greenwood Publishing Group. p. 346. ISBN 978-0-275-98883-8.

Phelan, S. E. \& Lewin, P. "Arriving at a strategic theory of the firm," International Journal of Management Reviews, (2:4), 2000, pp. 305323.

Rumelt, R. P., "How Much does Industry Matter?" Strategic Management Journal, Vol. 12, No. 3, 1991, pp. 167-185.

Sascha Friesike et al, (2009), 'SME-IP 3rd Report Case Studies on SMEs and Intellectual Property in Switzerland'.

SME administration Affairs, Taiwan "Announced White Book in 2008".

SME administration Affairs, Taiwan "Announced White Book in 2010".

SME administration Affairs, Taiwan "Announced White Book in 2016".

SME administration Affairs, Taiwan "Announced White Book in 2017",

Storey, D. J. (1994). Understanding the small business sector. London: Routledge.

Taiwan Stock Exchange Corporation (TWSE), 2018, "IPO search Engine"

TIPO Patent Act 2017.

TIPO Search for patents 2017.

TIPO Search for Trademark 2017.

TIPO Trademark Act 2016.

Trade Marks Act 1995 (the Trade Marks Act), A guide to applying for your Trade Mark.

U. S. Small Business Administration, (2010) 'Table of Small Business Size Standards Matched to North American Industry Classification System Codes.

Wayne Wittig et al, (1998) 'A Practical Guide for Assessing and Developing Public Procurement Programmes to Assist SMEs'.WIPO Intellectual Property Handbook: Policy, Law and Use. Chapter 2: Fields of Intellectual Property Protection WIPO 2008.

World Intellectual Property Organisation. "Understanding Copyright and Related Rights" (PDF). WIPO. p. 8. Archived from the original (PDF) on 2012-03-19.

World Trade Organization. (1994). 'WTO Agreements, Annex 1C: Agreement on Trade-Related Aspects of Intellectual Property'.

Lemley MA (2005) Property as a common descriptor of the field probably traces to the foundation of the World Intellectual Property Organization (WIPO) by the United Nations, Property, Intellectual Property and Free Riding. Tex Law Rev 83: 1031-1033. 
Ching-Yung Wang., Adv. J Social Sci.; Vol. 3 Issue 1, pp: 8-22, 2018

"What are intellectual property rights?". World Trade Organization. World Trade Organization. Retrieved 2016-05-23.ated Aspects of Intellectual Property.

Van Den Bulcke, (2003), "Internationalization towards China after its Accession to the WTO-- Are There Opportunities for European SMEs?"

Publish your research article in AIJR journals-

$\checkmark$ Online Submission and Tracking

$\checkmark$ Peer-Reviewed

$\checkmark$ Rapid decision

$\checkmark$ Immediate Publication after acceptance

$\checkmark$ Articles freely available online

$\checkmark$ Retain full copyright of your article.

Submit your article at journals.aijr.in
Publish your books with AIJR publisher-

$\checkmark \quad$ Publish with ISBN and DOI.

$\checkmark$ Publish Thesis/Dissertation as Monograph.

$\checkmark$ Publish Book Monograph.

$\checkmark$ Publish Edited Volume/ Book.

$\checkmark$ Publish Conference Proceedings

$\checkmark \quad$ Retain full copyright of your books.

Submit your manuscript at books.aijr.org 